\title{
Strong Nonagricultural Demand Keeps Agricultural Land Values Increasing ${ }^{1}$
}

John E. Reynolds²

The Florida Land Value Survey, conducted by the Food and Resource Economics Department at the University of Florida, provides estimates of the value of different types of agricultural land for geographic regions of the state. The survey questionnaire was designed to obtain estimates of the market value for different types of land as of May 2005. Survey respondents included rural appraisers, farm lenders, real estate brokers, farm managers, land investors, county extension agents, personnel from the Farm Services Agency and the Natural Resource Conservation Service, county property appraisers, and other persons who develop and maintain information about rural land values in their areas. Respondents provided 185 usable county reports for the 2005 survey.

The state was divided, based on agricultural production, into five major regions: Northwest, Northeast, Central, South, and Southeast (Figure 1). The Southeast was delineated as a result of the impact of urbanization in southeast Florida. Even though the state was divided into more homogeneous regions, wide variation in agricultural land values still exists within each region.

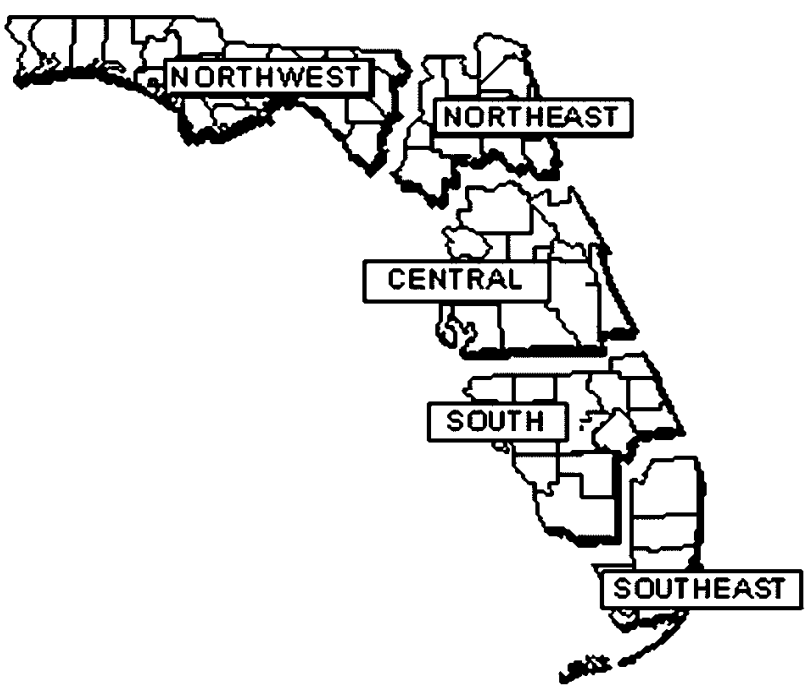

Figure 1. Geographic regions used for the Florida land value survey.

\section{Summary of Results}

The 2005 Florida Land Value Survey results indicated that the value of all types of agricultural land increased substantially in all regions of the state from 2004 to 2005. The market for agricultural land

1. This is EDIS document FE625, a publication of the Food and Resource Economics Department, Florida Cooperative Extension Service, Institute of Food and Agricultural Sciences, University of Florida, Gainesville, FL. Published January 2006. Please visit the EDIS website at http://edis.ifas.ufl.edu.

2. John Reynolds, Professor Emeritus, Food and Resource Economics Department, Florida Cooperative Extension Service, Institute of Food and Agricultural Sciences, University of Florida, Gainesville, FL, and Appraiser/Economist, Natural REsource Planning Services, 5700 SW 34th Street, Suite 324, Gainesville, FL.

The Institute of Food and Agricultural Sciences (IFAS) is an Equal Opportunity Institution authorized to provide research, educational information and other services only to individuals and institutions that function with non-discrimination with respect to race, creed, color, religion, age, disability, sex, sexual orientation, marital status, national origin, political opinions or affiliations. U.S. Department of Agriculture, Cooperative Extension Service, University of Florida, IFAS, Florida A. \& M. University Cooperative Extension Program, and Boards of County Commissioners Cooperating. Larry Arrington, Dean 
was very active this past year and the rate of increase in land values was particularly high in all regions. The percentage change ranged from 50 to 88 percent. Land values varied by the type of land use and geographic area. The survey results indicate that the average value of agricultural land ranges from approximately $\$ 2,700$ per acre for unimproved pasture and farm woods in the Northwest region to almost $\$ 10,000$ for orange groves in the Central and South regions.

Survey respondents indicated that the increases in the value of agricultural lands were primarily due to a strong nonagricultural demand for land. They indicated that farmland was not being purchased for agricultural purposes in most cases, and that the income from the agricultural use was not a primary consideration in the purchase. Other factors that were identified as affecting the value of agricultural land included the investment of "1031 like-kind exchange" money, speculation by out-of-town buyers and developers, investment by foreign buyers, the strong demand for rural home sites, and buyers using land as an alternative investment due to the volatility and uncertainty in the stock market.

\section{Changes by Type of Land Use}

The value of agricultural land increased in all regions. The value of cropland increased by 67 to 85 percent, and the value of improved and unimproved pastureland increased by 76 to 87 percent. The value of farm woods increased 81 to 84 percent. Although citrus groves did not increase as much as cropland and pasture, the value of orange groves and 5- to 7 -year-old citrus groves increased 51 to 58 percent, and the value of grapefruit groves increased 81 to 88 percent (Table 1).

Citrus. The value of orange and grapefruit groves increased in both the Central and South regions. The value of orange groves increased 52 percent in the South region and 53 percent in the Central region. The value of grapefruit groves increased 88 percent in the South region and 81 percent in the Central region. The value of land with 5- to 7-year-old citrus plantings increased about 51 percent in the South region and 58 percent in the Central region.
Cropland. The value of cropland increased in all regions. The value of irrigated cropland increased 67 percent in the South region, 85 percent in the Northeast region and about 83 percent in the Northwest region. The value of nonirrigated cropland increased 69 percent in the Northwest and Northeast regions. There were insufficient data on the value of nonirrigated cropland in the Central and South regions to provide a reliable estimate.

Pastureland. The value of pastureland also increased in all regions. The value of pastureland increased approximately 81 percent in the South region and 78 to 82 percent in the Central region. The value of improved pasture increased 85 to 87 percent in the northern regions. The value of unimproved pasture increased 76 percent in the Northeast and 82 percent in the Northwest.

Farm Woods. The value of farm woods increased 84 percent in the Northwest region and 81 percent in the Northeast region.

\section{Regional Comparisons of Agricultural Land Values}

The most prominent change among regions this year was in the South region where the value increased from 66 to 81 percent for cropland and pastureland. The largest increases were in the Indian River area, Okeechobee County and the Gulf Coast counties. The other regions also experienced substantial increases: 78 to 82 percent in the Central region, 69 to 85 percent in the Northwest region and 69 to 87 percent in the Northeast region.

The average value of citrus land was higher in the South region than in the Central region. The value of cropland and pastureland increased from $\$ 2,100$ to $\$ 2,700$ per acre in the South region during the past year. The value of improved pasture was higher in the Central region than in other regions. The lowest agricultural land values were reported in the Northwest region ranging from $\$ 2,645$ per acre for unimproved pasture to $\$ 4,012$ per acre for irrigated cropland.

The average value of orange groves was $\$ 9,956$ per acre in the South region (about $\$ 150$ per acre higher than in the Central region). The estimated 
value of grapefruit groves increased to $\$ 9,897$ per acre in the South region $(\$ 1,705$ per acre higher than in the Central region). The average value of land with 5 - to 7 -year-old citrus groves was $\$ 8,944$ per acre in the South region ( $\$ 483$ per acre higher than in the Central region).

The value of irrigated cropland was $\$ 6,509$ per acre in the South region, $\$ 6,356$ in the Northeast region, and $\$ 4,012$ per acre in the Northwest region. The value of nonirrigated cropland was $\$ 4,490$ in the Northeast region and $\$ 3,332$ in the Northwest region.

The value of improved pasture ranged from $\$ 6,426$ per acre in the Central region to $\$ 3,337$ per acre in the Northwest region. The value of unimproved pasture ranged from $\$ 4,715$ per acre in the South region to $\$ 2,645$ per acre in the Northwest region. The value of improved pastureland in the South region was 91.7 percent of the value in the Central region. However, the value of unimproved pasture was 14 percent higher in the South than in the Central region. The value of both types of pastureland in the Northwest region was about 66 percent of those in the Northeast region.

\section{Transition Land}

Transition land is defined as agricultural land that is being converted or likely to be converted to nonagricultural uses as sites for homes, subdivisions, and commercial uses. Counties were divided into metropolitan and non-metropolitan counties and transition land values were estimated for each region. Metropolitan statistical areas (MSA) are classified by the U.S. Office of Management and Budget and are considered urban or urbanizing areas.

Non-metropolitan statistical areas are the rural counties not included in the metropolitan statistical areas. Six counties were re-classified in June 2003 and the new classifications are used in this analysis. The changes in the Northwest included moving Jefferson and Wakulla Counties into the Tallahassee MSA. Changes in the Northeast involved moving Gilchrist County into the Gainesville MSA and removing Flagler County from the MSA counties. In the South region, Indian River County was designated as the Vero Beach MSA. The transition land values for 2004 included moving these counties into the new MSA classifications. Therefore, the 2005 estimates are based on comparable counties with the 2004 estimates. Transition land values in the Southeast region were about three times more than in the other regions (Table 2).

The value of transition land within five miles of a major town in metropolitan counties increased from 31 to 120 percent from 2004 to 2005 . The value of transition land within five miles of a major town in metropolitan counties ranged from $\$ 18,423$ to $\$ 46,481$ per acre, except in the Southeast region where transition land values were $\$ 137,500$ per acre. The value of transition land more than five miles from a major town in metropolitan counties ranged from $\$ 10,758$ to $\$ 23,575$ per acre, except in the Southeast region where transition land values were $\$ 66,667$ per acre. The value of transition land within five miles of a major town in non-metropolitan counties ranged from $\$ 6,167$ to $\$ 17,143$ per acre, while transition land values more than five miles from a major town in non-metropolitan counties ranged from $\$ 5,333$ to $\$ 10,600$ per acre.

\section{Cash Rents}

The estimated annual cash rent for nonirrigated cropland was about $\$ 38$ per acre in the Northwest region and $\$ 35$ per acre in the Northeast region (Table 3). The estimated cash rent for improved pastureland was about \$29 per acre in the Northwest region, \$26 per acre in the Northeast region, \$22 per acre in the Central region, and $\$ 24$ per acre in the South region. Cash rent for unimproved pastureland ranged from about $\$ 21$ per acre in the Northwest region to $\$ 17$ per acre in the South region. The cash rent data indicate that cash rents increased for cropland and pasture in all regions where adequate data were available.

Although cash rents increased, the value of the different types of land increased much more than cash rents. As a result, cash rent was less than 1 percent of the value of the land for the different types of cropland and pasture. These rates are low compared to other areas of the country and reflect the effect of the strong nonagricultural demand for land on the market value of agricultural and rural land in all areas of Florida. 


\section{Expected Trends}

Survey respondents were asked if they expected agricultural land values to be higher, lower, or remain unchanged during the next 12 months. Eighty-two percent of the respondents in the northern areas and 88 percent in the southern areas expected agricultural land values to increase during the next year (Table 4). Only 3 percent of the respondents in the southern areas expected lower land values during the next 12 months. None of the respondents in the northern areas expected land values to decline. Respondents expected land values to increase from 14 to 25 percent during the next 12 months. Agricultural land values are expected to increase 14 percent in the Northwest region and 25 percent in the Northeast region during the next year. In both the Central and South regions, respondents expect agricultural land values to increase 19 percent. Respondents in the Southeast region expect land values to increase 23 percent.

\section{Use of the Survey Results}

The estimates of land values provided in this report are based on the opinions of many people involved in the real estate market. Care must be exercised when making year-to-year comparisons between surveys for several reasons. First, the group of participating respondents changes from year to year. Second, some of the land use categories in some regions have fewer responses than previous years and the statistical reliability differs from year to year. Finally, with these changes and changes in the counties designated as MSA counties, the results may not be directly comparable with results from previous years.

Despite these limitations, this survey has provided estimates of agricultural land values that have been fairly consistent since the mid-1980s. These estimates serve as a guide to the relative average value of different land uses within areas and between areas. It is important, however, to emphasize that the value of a specific tract of land may vary substantially from these estimates because of the physical characteristics of the tract, the location of the tract, and the economic and institutional factors that may affect or restrict its use. Therefore, the value of a specific tract of land should not be determined by these survey results.

\section{References}

Reynolds, John E. 2004. Nonagricultural Demand Causes Agricultural Land Values to Increase. Electronic Digital Information Source (EDIS) FE545, Food and Resource Economics Department, University of Florida, Gainesville, FL. http://edis.ifas.ufl.edu/FE545, and at http://www.agbuscenter.ifas.ufl.edu/landuse (University of Florida IFAS Extension FE545). 
Table 1. Estimated land value per acre, by geographic region and land use, 2004 and 2005.

\begin{tabular}{|c|c|c|c|}
\hline \multirow[t]{2}{*}{ Region/Land Use } & \multicolumn{2}{|c|}{ Dates } & \multirow[t]{2}{*}{ Percent Change } \\
\hline & May 2004 & May 2005 & \\
\hline & \multicolumn{2}{|c|}{ Dollars Per Acre } & \\
\hline \multicolumn{4}{|l|}{ SOUTH } \\
\hline Mature Oranges & 6,540 & 9,956 & 52.2 \\
\hline Mature Grapefruit & 5,264 & 9,897 & 88.0 \\
\hline 5-7 Year Citrus & 5,920 & 8,944 & 51.1 \\
\hline \multicolumn{4}{|l|}{ Cropland } \\
\hline Irrigated & 3,901 & 6,509 & 66.9 \\
\hline Nonirrigated & $* * *$ & $* * *$ & $* * *$ \\
\hline \multicolumn{4}{|l|}{ Pastureland } \\
\hline Improved & 3,262 & 5,895 & 80.7 \\
\hline Unimproved & 2,605 & 4,715 & 81.0 \\
\hline \multicolumn{4}{|l|}{ CENTRAL } \\
\hline Mature Oranges & 6,409 & 9,805 & 53.0 \\
\hline Mature Grapefruit & 4,518 & 8,192 & 81.3 \\
\hline 5-7 Year Citrus & 5,340 & 8,461 & 58.4 \\
\hline \multicolumn{4}{|l|}{ Cropland } \\
\hline Irrigated & 3,709 & $* \star \star$ & $* \star \star$ \\
\hline Nonirrigated & 3,237 & 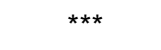 & 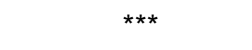 \\
\hline \multicolumn{4}{|l|}{ Pastureland } \\
\hline Improved & 3,608 & 6,426 & 78.1 \\
\hline Unimproved & 2,267 & 4,133 & 82.3 \\
\hline \multicolumn{4}{|l|}{ NORTHEAST } \\
\hline \multicolumn{4}{|l|}{ Cropland } \\
\hline Irrigated & 3,428 & 6,356 & 85.4 \\
\hline Nonirrigated & 2,657 & 4,490 & 69.0 \\
\hline \multicolumn{4}{|l|}{ Pastureland } \\
\hline Improved & 2,729 & 5,052 & 85.1 \\
\hline Unimproved & 2,268 & 3,992 & 76.0 \\
\hline Farm Woods & 2,140 & 3,864 & 80.6 \\
\hline \multicolumn{4}{|l|}{ NORTHWEST } \\
\hline \multicolumn{4}{|l|}{ Cropland } \\
\hline Irrigated & 2,193 & 4,012 & 82.9 \\
\hline Nonirrigated & 1,983 & 3,332 & 69.0 \\
\hline \multicolumn{4}{|l|}{ Pastureland } \\
\hline Improved & 1,783 & 3,337 & 87.2 \\
\hline Unimproved & 1,451 & 2,645 & 82.3 \\
\hline Farm Woods & 1,464 & 2,700 & 84.4 \\
\hline
\end{tabular}


Table 2. Estimated value of transition land, by geographic region, May 2005.

\begin{tabular}{|c|c|c|c|}
\hline \multirow[t]{2}{*}{ Region/Category } & \multicolumn{2}{|c|}{ Dates } & \multirow[t]{2}{*}{ Percent Change } \\
\hline & May 2004 & May 2005 & \\
\hline & \multicolumn{2}{|c|}{ Dollars Per Acre } & \\
\hline \multicolumn{4}{|l|}{ METROPOLITAN COUNTIES } \\
\hline \multicolumn{4}{|c|}{$<5$ Miles to Major Town } \\
\hline Northwest & 14,082 & 18,423 & 30.8 \\
\hline Northeast & 17,751 & 32,286 & 94.7 \\
\hline Central & 18,575 & 36,472 & 96.3 \\
\hline South & 24,983 & 46,481 & 86.1 \\
\hline Southeast & 62,500 & 137,500 & 120.0 \\
\hline \multicolumn{4}{|c|}{$>5$ Miles to Major Town } \\
\hline Northwest & 7,950 & 10,758 & 35.3 \\
\hline Northeast & 9,023 & 12,750 & 38.2 \\
\hline Central & 12,500 & 23,575 & 88.6 \\
\hline South & 14,352 & 21,612 & 50.6 \\
\hline Southeast & 36,250 & 66,667 & 83.9 \\
\hline \multicolumn{4}{|c|}{ NON-METROPLITAN COUNTIES } \\
\hline \multicolumn{4}{|c|}{$<5$ Miles to Major Town } \\
\hline Northwest & 4,793 & 6,167 & 43.7 \\
\hline Northeast & 6,473 & 12,600 & 94.7 \\
\hline Central & *** & 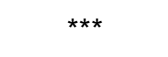 & $\star \star \star *$ \\
\hline South & 6,778 & 17,143 & 152.9 \\
\hline \multicolumn{4}{|c|}{$>5$ Miles to Major Town } \\
\hline Northwest & 3,921 & 5,333 & 36.0 \\
\hline Northeast & 5,446 & 10,500 & 92.8 \\
\hline Central & 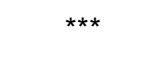 & $* \star \star$ & *** \\
\hline South & 4,833 & 10,600 & 104.6 \\
\hline
\end{tabular}


Table 3. Cash rent, by geographic region, May 2005.

\begin{tabular}{|c|c|c|c|c|}
\hline Item & Northwest & Northeast & Central & South \\
\hline & \multicolumn{4}{|c|}{ Dollars Per Acre } \\
\hline Improved Pastureland & 28.57 & 25.60 & 22.11 & 24.33 \\
\hline Unimproved Pastureland & 21.11 & 19.79 & *** & 17.06 \\
\hline Nonirrigated Cropland & 38.19 & 35.06 & *** & *** \\
\hline
\end{tabular}

Table 4. Respondents' expectations land value changes over the next 12 months, by geographic region, May 2005.

\begin{tabular}{|lccc|}
\hline \hline Item & Higher Expectations & No Change & Lower Expectations \\
\hline & & Percentage of Responses & \\
Southern Areas & 88 & 9 & 3 \\
Northern Areas & 82 & 18 & 0 \\
\hline \hline
\end{tabular}

